\title{
Effect of Zirconium and Cerium Loadings on Aerogel Pd-Based Catalysts for Methane Combustion
}

\author{
Khouloud Sadouki', Shemseddine Fessi',2, Zouhaier Ksibi', Mickael Capron³, \\ Franck Dumeignil $^{3}$, Abdelhamid Ghorbel ${ }^{1}$
}

\author{
${ }^{1}$ Laboratoire de Chimie des Matériaux et Catalyse, Département de Chimie, Faculté des Sciences de Tunis, Université Tunis-El \\ Manar, Campus Universitaire, Tunis, Tunisie \\ ${ }^{2}$ Chemistry Department, Faculty of Science and Arts, University of Jeddah, Jeddah, Saudi Arabia \\ ${ }^{3}$ Univ. Lille, CNRS, Centrale Lille, ENSCL, Univ. Artois, UMR 8181-UCCS-Unité de Catalyse et Chimie du Solide, \\ Lille, France \\ Email: khouloud.sadouki21@gmail.com
}

How to cite this paper: Sadouki, K., Fessi, S., Ksibi, Z., Capron, M., Dumeignil, F. and Ghorbel, A. (2018) Effect of Zirconium and Cerium Loadings on Aerogel Pd-Based Catalysts for Methane Combustion. Advances in Materials Physics and Chemistry, 8, 105-119.

https://doi.org/10.4236/ampc.2018.83008

Received: November 8, 2017

Accepted: March 13, 2018

Published: March 16, 2018

Copyright $\odot 2018$ by authors and Scientific Research Publishing Inc. This work is licensed under the Creative Commons Attribution International License (CC BY 4.0).

http://creativecommons.org/licenses/by/4.0/

\begin{abstract}
Aerogel $\mathrm{Pd} /\left(\mathrm{Ce}_{0.33} \mathrm{Zr}_{0.66} \mathrm{O}_{2}\right) \mathrm{SiO}_{2}$ catalysts (CeZry) were prepared with variable $\mathrm{Ce}$ and $\mathrm{Zr}$ loadings (molar ratio $\mathrm{Ce} / \mathrm{Zr}=1 / 2$ ) by combining sol-gel and impregnation methods. First, $\mathrm{N}_{2}$-physisorption was used to investigate the texture evolution. Then, $\mathrm{H}_{2}$-chimisorption and TEM were performed to study the effect on particle dispersion. After, TPR was used to determine the catalyst reducibility. Furthermore, XPS characterization was done to identify the palladium oxidation state and to evaluate the Pd-support interaction. Finally, the prepared catalysts were tested in methane combustion to assess their catalytic activity. The obtained results showed that, when the $\mathrm{Zr}$ and Ce loadings are varied between $0 \%$ and $8 \%$ and between $0 \%$ and $6 \%$ respectively, the BET surface area was increased from 615 to $744 \mathrm{~m}^{2} / \mathrm{g}$, the porosity diameter from 45.7 to $83.6 \AA$, the $\mathrm{Pd}$ particle diameter from 5.2 to $7.0 \mathrm{~nm}$, the $\mathrm{CeO}_{2}$ and $\mathrm{ZrO}_{2}$ particle size from 0 to $68 \mathrm{~nm}$, the reduction temperature shift reached $16^{\circ} \mathrm{C}$, the Pd binding energy shift attained $0.6 \mathrm{eV}$, but an optimum amounts of $\mathrm{Zr}$ (4 wt.\%) and Ce ( 3 wt.\%) are needed to maximize the PdO reducibility and to enhance the catalytic activity. In effect, $100 \%$ conversion of methane was reached at around $415^{\circ} \mathrm{C}$ on the $\mathrm{CeZr} 4$ catalyst.
\end{abstract}

\section{Keywords}

$\mathrm{Pd} /\left(\mathrm{CexZr}_{(1-\mathrm{x})} \mathrm{O}_{2}\right) / \mathrm{SiO}_{2}$ Catalysts, Methane Combustion, Catalytic Activity 


\section{Introduction}

Methane is an economical and clean alternative to fuels; it is used to produce energy in gas turbine combustors and as a new energy for vehicles [1]. The advantage of catalytic combustion of methane is that operates at much lower temperatures than flame combustion, which greatly reduces the noxious emissions of nitrogen oxides, $\mathrm{NO}_{\mathrm{x}}$ and unburned hydrocarbons [2]. Palladium oxide is considered to be an effective catalyst in methane oxidation [3] [4] [5] [6]. Unfortunately, the deactivation of the catalyst due to the sintering of palladium during heat treatments is a serious problem for this kind of catalysts [7]. Therefore, it is necessary to modify the Pd-base catalysts to improve their thermal stability. Among the parameter which may affect the thermal stability of the catalyst are the support and the additives [8]. The ceria-zirconia-supported palladium catalysts showed high activity [9] [10] due to $\mathrm{CeO}_{2}-\mathrm{ZrO}_{2}$ redox properties and oxygen storage capacity (OSC) which is better than pure $\mathrm{CeO}_{2}$ [9] [10] [11] [12]. The addition of zirconium into the cubic $\mathrm{CeO}_{2}$ framework is effective to prevent cerium sintering, to improve the oxygen mobility in the lattice and to increase thermal stability [13]. Furthermore, the use of $\mathrm{SiO}_{2}$ as a support could promote OSC because of its relatively higher dispersive properties due to its relatively high surface area, and because its relatively inert character compared to other supports [14], which prevent $\mathrm{CeO}_{2}$ depletion through, e.g., reaction with the support giving compounds such as $\mathrm{CeAlO}_{3}$ formation causing the OSC decrease when $\mathrm{Al}_{2} \mathrm{O}_{3}$ is used [15]. However, studies on aerogel $\mathrm{SiO}_{2}$ as a support for $\mathrm{Ce}_{\mathrm{x}} \mathrm{Zr}_{1-\mathrm{x}} \mathrm{O}_{2}$ oxide have been scarcely reported, especially when concerning the effect of $\mathrm{Ce}_{\mathrm{x}} \mathrm{Zr}_{1-\mathrm{x}} \mathrm{O}_{2}$ loading on the $\mathrm{Pd} /\left(\mathrm{Ce}_{\mathrm{x}} \mathrm{Zr}_{1-\mathrm{x}} \mathrm{O}_{2}\right) \mathrm{SiO}_{2}$ catalyst for methane combustion. For these reasons, in the research presented herein, the sol-gel process was used to prepare a $\mathrm{SiO}_{2}$ aerogel known to have a relatively high specific surface area, which enables relatively better dispersion of cerium and zirconium oxides and lower thickness of the pore walls, which increase oxygen mobility [17]. However appropriate amounts of $\mathrm{Ce}$ and $\mathrm{Zr}$ are needed to make the modification efficient [16]. The impregnation method was then used to add palladium and to prepare the $\mathrm{Pd} /\left(\mathrm{Ce}_{0.33} \mathrm{Zr}_{0.66} \mathrm{O}_{2}\right) \mathrm{SiO}_{2}$ catalysts. The effect of $\mathrm{Ce}$ and $\mathrm{Zr}$ loadings on the texture, the structure and the catalytic activity in methane combustion was then studied.

\section{Experimental}

\subsection{Chemicals}

Cerium nitrate $\mathrm{Ce}\left(\mathrm{NO}_{3}\right)_{3} \cdot 6 \mathrm{H}_{2} \mathrm{O}$ (Sigma-Aldrich, 99.99\%), zirconium(IV) oxynitrate hydrate $\mathrm{ZrO}\left(\mathrm{NO}_{3}\right)_{3} \cdot \mathrm{xH}_{2} \mathrm{O}$ (Sigma-Aldrich, 99.99\%), ethanol $\mathrm{C}_{2} \mathrm{H}_{5} \mathrm{OH}$ (Sigma-Aldrich, $\geq 99.8 \%$ ), tetraethyl orthosilicate $\mathrm{Si}\left(\mathrm{OC}_{2} \mathrm{H}_{5}\right)_{4}$ (TEOS) (ACROS, 98\%), acetic acid $\mathrm{CH}_{3} \mathrm{COOH}$ (Sigma-Aldrich, $\geq 99.7 \%$ ) and palladium acetate $\left(\mathrm{Pd}(\mathrm{OAc})_{2}\right)$ (Fluka, 35.5\% Pd) are used as chemicals in this work. 


\subsection{Support Preparation}

The $\left(\mathrm{Ce}_{0.33} \mathrm{Zr}_{0.66} \mathrm{O}_{2}\right) \mathrm{SiO}_{2}$ support was prepared by sol-gel method with variable Ce and $\mathrm{Zr}$ loadings ( $\mathrm{Zr} \%=0,2,4$ and 8 wt.\%) and a fixed molar ratio $\mathrm{Zr} / \mathrm{Ce}=2$. $\mathrm{Ce}\left(\mathrm{NO}_{3}\right)_{3} \cdot 6 \mathrm{H}_{2} \mathrm{O}, \mathrm{ZrO}\left(\mathrm{NO}_{3}\right)_{3} \cdot \mathrm{xH}_{2} \mathrm{O}, \mathrm{CH}_{3} \mathrm{COOH}, \mathrm{Si}\left(\mathrm{OC}_{2} \mathrm{H}_{5}\right)_{4}(\mathrm{TEOS})$, ethanol and deionized water were mixed at $40^{\circ} \mathrm{C}$. The molar ratios of $\mathrm{H}_{2} \mathrm{O} / \mathrm{TEOS}=15$ and $\mathrm{CH}_{3} \mathrm{COOH} / \mathrm{TEOS}=1$. The obtained sol was maintained under constant stirring until a spongy and transparent gel was formed. The solvent was then removed by evaporation under supercritical conditions of ethanol $\left(T_{c}=240.9^{\circ} \mathrm{C}, P_{c}=6.14\right.$ $\mathrm{MPa}$ ). Finally, the obtained solid was calcined at $550^{\circ} \mathrm{C}$ for $4 \mathrm{~h}$ under oxygen flow $(30 \mathrm{~mL} / \mathrm{min})$.

\subsection{Catalyst Preparation}

The $\mathrm{Pd} /\left(\mathrm{Ce}_{0.33} \mathrm{Zr}_{0.66} \mathrm{O}_{2}\right) \mathrm{SiO}_{2}$ catalysts (CeZry, where $\mathrm{y}$ is the $\mathrm{Zr}$ loading) were prepared by the impregnation method. The appropriate amounts of palladium acetate and $\left(\mathrm{Ce}_{0.33} \mathrm{Zr}_{0.66} \mathrm{O}_{2}\right) \mathrm{SiO}_{2}$ solid were ground in an agate mortar for $10 \mathrm{~min}$. The chosen loading of Pd was 0.5 wt.\%. Then, acetone was added $(1 \mathrm{~mL} / \mathrm{g})$ to obtain a paste which was dried at $60^{\circ} \mathrm{C}$ and calcined at $550^{\circ} \mathrm{C}$ for $2 \mathrm{~h}$ under oxygen flow $(30 \mathrm{~mL} / \mathrm{min})$.

\subsection{Catalyst Characterization}

The BET specific surface area and the average pore diameter were determined from $\mathrm{N}_{2}$ adsorption-desorption measurements using an automatic Micrometrics ASAP 2020 device (error percentage: 5\%). Hydrogen chemisorption measurements were performed at $100^{\circ} \mathrm{C}$ in a Micromeritics ASAP 2020C equipment after an in-situ reduction treatment under hydrogen at $300^{\circ} \mathrm{C}$ for $2 \mathrm{~h}$. Temperature programmed reduction (TPR) was performed with $\mathrm{H}_{2}$ using a quartz U-tube reactor, coupled to a thermal conductivity detector (TCD). The catalyst $(0.05 \mathrm{~g})$ was dried at $250^{\circ} \mathrm{C}$ during $0.5 \mathrm{~h}$ under argon flow (AGA, 99.99\%) and reduced with $10 \mathrm{v} / \mathrm{v} \% \mathrm{H}_{2} / \mathrm{Ar}$ flow $(30 \mathrm{ml} / \mathrm{min})$ from $25^{\circ} \mathrm{C}$ to $400^{\circ} \mathrm{C}\left(10^{\circ} \mathrm{C} / \mathrm{min}\right)$. TEM studies were performed on a TECNAI G2 instrument operating at $200 \mathrm{kV}$ (error percentage: $2 \%$ ). The XPS analyses were conducted on calcined samples using a Kratos Analytical AXIS UltraDLD spectrometer (the error percentage was below 1\%). The catalytic activity for methane combustion was determined over the calcined sample $(0.1 \mathrm{~g})$ in a dynamic micro-reactor.

A flow comprising 1 vol.\% methane, 4 vol.\% oxygen and balanced with helium was mixed and regulated at a total flow of $100 \mathrm{~mL} / \mathrm{min}$. The reactor effluent was then analyzed by a thermal conductivity detector at different reaction temperatures.

The methane conversion and the turnover frequencies (TOF) were calculated by the following equations:

$$
\text { Conversion }(\%)=\frac{\mathrm{P}_{\mathrm{CO}_{2}}}{\mathrm{P}_{\mathrm{CH}_{4}}+\mathrm{P}_{\mathrm{CO}_{2}}} \times 100
$$


$\mathrm{P}_{\mathrm{CH}_{4}}$ and $\mathrm{P}_{\mathrm{CO}_{2}}$ are respectively, the partial pressures of methane and carbon dioxide.

$$
\begin{aligned}
& \text { TOF }=\frac{\mathrm{A} \times \mathrm{M}_{\mathrm{Pd}}}{\mathrm{l} \times \mathrm{D}} \\
& \mathrm{A}=\frac{\mathrm{P}_{\mathrm{CO}_{2}} \times \mathrm{D}_{\mathrm{T}} \times 273}{22.4 \times \mathrm{T}_{\mathrm{r}} \times \mathrm{m}}
\end{aligned}
$$

A: catalyst activity (\%), $\mathrm{M}_{\mathrm{Pd}}$ : atomic mass of palladium $(106.42 \mathrm{~g} / \mathrm{mol}), \mathrm{l}: \mathrm{Pd}$ loading (wt\%), $\mathrm{D}_{\mathrm{T}}$ : total gas flow $(\mathrm{L} / \mathrm{h}), \mathrm{T}_{\mathrm{r}}$ : room temperature, $\mathrm{m}$ : catalyst weight (g) and $\mathrm{D}$ the dispersion (\%).

\section{Results and Discussion}

\subsection{Nitrogen Physisorption}

The $\mathrm{N}_{2}$-physisorption results of the $\mathrm{Pd} /\left(\mathrm{Ce}_{0.33} \mathrm{Zr}_{0.66} \mathrm{O}_{2}\right) \mathrm{SiO}_{2}$ catalysts summarized in Table 1 show that the textural properties of the solids were significantly modified when the $\mathrm{Ce}$ and $\mathrm{Zr}$ loadings were increased. Indeed, the pore volume varied between 0.83 and $1.68 \mathrm{~cm}^{3} / \mathrm{g}$, the average pore diameter between 45.7 and $83.6 \AA$ and the BET specific surface area between 615 and $744 \mathrm{~m}^{2} / \mathrm{g}$, (see Table 1). As can be noted, the surface area of $\mathrm{Pd} /\left(\mathrm{Ce}_{0.33} \mathrm{Zr}_{0.66} \mathrm{O}_{2}\right) \mathrm{SiO}_{2}$ was larger than that of $\mathrm{Pd} / \mathrm{SiO}_{2}$. These results showed that there is an interaction between $\mathrm{CeO}_{2}-\mathrm{ZrO}_{2}$ and $\mathrm{SiO}_{2}$, which resulted in an increase in surface area of support, similar phenomenon has been observed in the literature [17]. Which suggest that this interaction can enhance also the thermal stability of palladium supported catalysts. In addition, it is important to note, that all the adsorption-desorption isotherms were of type IV in the BDDT classification (Figure 1) and that hysteresis loops apparent on the all isotherms was identified as being of the H1 type (IUPAC), which is characteristic of cylindrical pores. These results suggest that the preparation method adopted in this work is able to produce mesoporous ceria-zirconia-silica supports with improved surface area when the Ce and $\mathrm{Zr}$ contents increase. In the present work, $8 \%$ of $\mathrm{Zr}$ and $6 \%$ of $\mathrm{Ce}$ allows yielding a $\mathrm{Pd} /\left(\mathrm{Ce}_{0.33} \mathrm{Zr}_{0.66} \mathrm{O}_{2}\right) \mathrm{SiO}_{2}$ catalyst with a relatively high surface area equal to 744 $\mathrm{m}^{2} / \mathrm{g}$.

Table 1. $\mathrm{Zr}$ and Ce weight contents, BET surface area $\mathrm{S}_{\mathrm{BET}}\left(\mathrm{m}^{2} / \mathrm{g}\right)$, average pore diameter Dp $(\AA)$, total pore volume $\mathrm{Vp}\left(\mathrm{cm}^{3} / \mathrm{g}\right)$, Pd dispersion $\mathrm{D}_{\mathrm{H} 2}(\%)$, average Pd particle diameter $\mathrm{d}_{\mathrm{H} 2}$ and average $\mathrm{CeO}_{2}-\mathrm{ZrO}_{2}$ particle diameter $\mathrm{d}_{\mathrm{TEM}}$ of the $\mathrm{Pd} /\left(\mathrm{Ce}_{0.33} \mathrm{Zr}_{0.66} \mathrm{O}_{2}\right)$ $\mathrm{SiO}_{2}$ catalysts.

\begin{tabular}{ccccccccc}
\hline Sample & $\mathrm{Zr}$ wt.\% & $\mathrm{Ce} \mathrm{wt. \%}$ & $\mathrm{S}_{\mathrm{BET}}{ }^{\mathrm{a}} \mathrm{m}^{2} / \mathrm{g}$ & $\mathrm{Dp}^{\mathrm{a}}(\AA)$ & $\mathrm{Vp}^{\mathrm{b}}\left(\mathrm{cm}^{3} / \mathrm{g}\right)$ & $\mathrm{D}_{\mathrm{H} 2}{ }^{\mathrm{c}}(\%)$ & $\mathrm{d}_{\mathrm{H} 2}(\mathrm{Pd})^{\mathrm{c}}(\mathrm{nm})$ & $\mathrm{d}_{\mathrm{TEM}}\left(\mathrm{CeO}_{2}-\mathrm{ZrO}_{2}\right)^{\mathrm{d}}\left(\mathrm{nm}^{2}\right)$ \\
\hline CeZr8 & 8 & 6 & 744 & 58.9 & 1.13 & 18 & 5.2 & 68 \\
$\mathrm{CeZr} 4$ & 4 & 3 & 734 & 83.6 & 1.68 & 17 & 5.6 & 32 \\
CeZr2 & 2 & 1.5 & 696 & 60.6 & 1.18 & 16 & 5.7 & 12 \\
CeZr0 & 0 & 0 & 615 & 45.7 & 0.83 & 14 & 7.0 & - \\
\hline
\end{tabular}

${ }^{\mathrm{a}}$ From $\mathrm{N}_{2}$ chemisorption at $77 \mathrm{~K}$ using the BET equation. ${ }^{\mathrm{b}}$ Total pore volume estimated at reduced pressure $\mathrm{P} / \mathrm{P}_{0}=0.99$, accuracy $\pm 0.01 \mathrm{~cm} / \mathrm{g}$. ${ }^{\mathrm{c}} \mathrm{Based}$ on $\mathrm{H}_{2}$ chemisorption measurements. ${ }^{\mathrm{d}}$ Estimated according to the TEM images. 

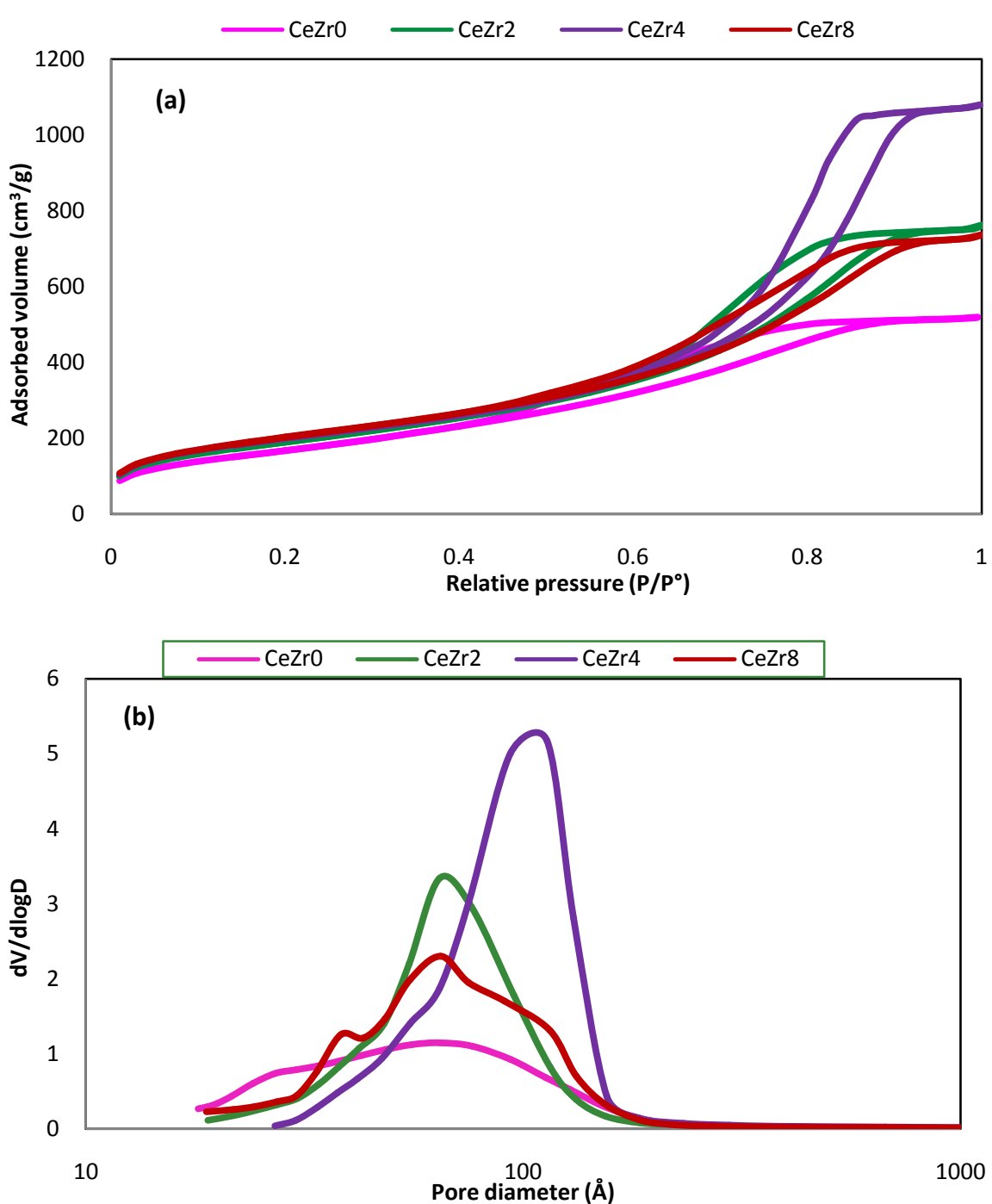

Figure 1. (a) Effect of the $\mathrm{Zr}$ and Ce loadings on the adsorption-desorption isotherm profile of the $\mathrm{Pd} /\left(\mathrm{Ce}_{0.33} \mathrm{Zr}_{0.66} \mathrm{O}_{2}\right) \mathrm{SiO}_{2}$ samples. (b) Average pore diameter distributions of the $\mathrm{Pd} /\left(\mathrm{Ce}_{0.33} \mathrm{Zr}_{0.66} \mathrm{O}_{2}\right) \mathrm{SiO}_{2}$ samples.

Furthermore, we can note that the average pore diameter $(\mathrm{Dp})$ and the total pore volume $(\mathrm{Vp})$ increase with the Ce and $\mathrm{Zr}$ loadings up to the CeZr4 catalyst, and then decrease on the CeZr8 sample. The highest Dp and Vp values obtained on the CeZr4 catalyst may affect the catalytic activity through the improvement of the matter and heat transfer limitations.

\subsection{Hydrogen Chemisorption}

The hydrogen chemisorption analyses were conducted on the $\mathrm{Pd} /\left(\mathrm{Ce}_{0.33} \mathrm{Zr}_{0.66} \mathrm{O}_{2}\right) \mathrm{SiO}_{2}$ in order to determine the dispersion and the particle sizes of palladium. The obtained results gathered in Table 1, show that the palladium dispersion was slightly improved when the $\mathrm{Zr}$ and Ce loadings increased (see Table 1). Indeed, the palladium dispersion increased from $14 \%$ on the CeZr0 sample to $18 \%$ on the CeZr8 catalyst. These results suggest that the Pd dispersion could be im- 
proved by the increasing the ceria-zirconia amounts [18], According to the previous work in our research group [13], this results explained by the sintering inhibition of the PdO particles. This improvement of thermal stability could be favored by the enhancement of the PdO-support interaction. In our work, the $\mathrm{Zr}$ and Ce loadings seem to be insufficient to improve significantly the Pd dispersion.

\subsection{TEM Characterization}

The TEM images of the $\mathrm{Pd} /\left(\mathrm{Ce}_{0.33} \mathrm{Zr}_{0.66} \mathrm{O}_{2}\right) \mathrm{SiO}_{2}$ samples are shown in Figure 2. Homogeneous distribution of the Pd particle size and a good dispersion of the
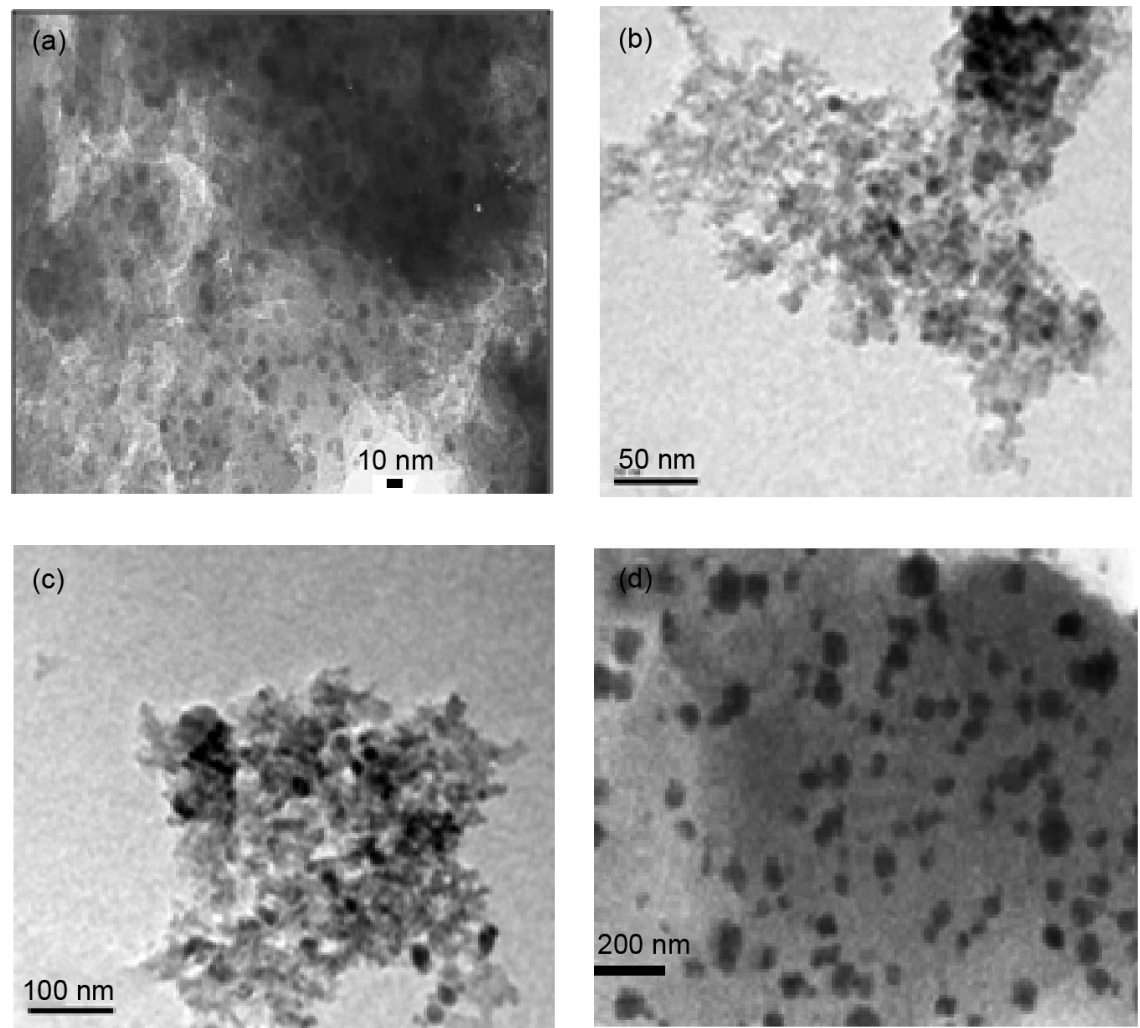

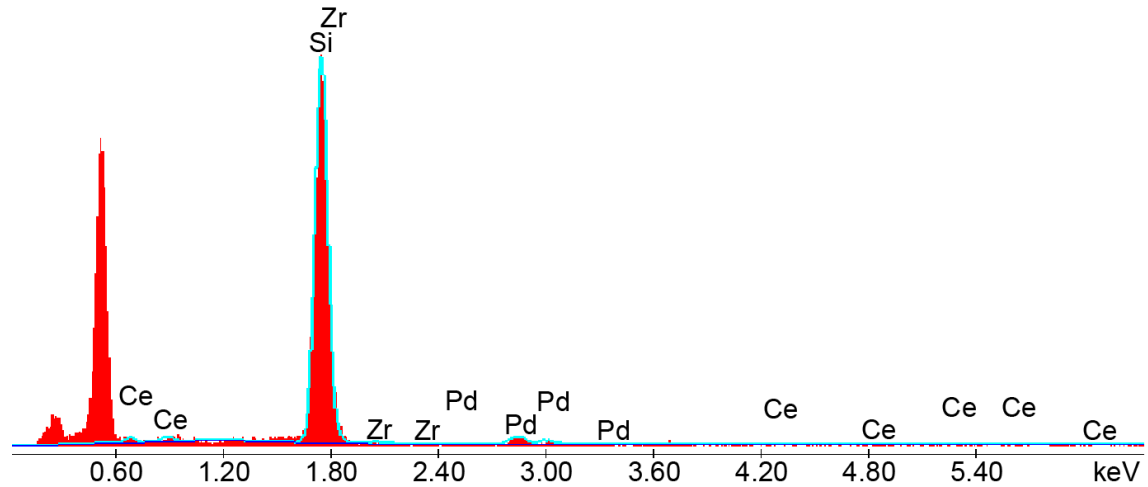

(e)

Figure 2. TEM images of the CeZr0 (a), CeZr2 (b), CeZr4 (c), CeZr8 (d) and EDXA of the CeZr4 catalysts (e). 
palladium particles are shown on CeZr0 micrograph. According to the particle size distribution, the average Pd particle size is about $6.9 \pm 2 \mathrm{~nm}$ (Figure 2(a)), which in a good agreement with data obtained from hydrogen chemisorption results. For the CeZr2 CeZr4 and CeZr8 micrographs, it is found therein that the morphologies of these catalysts are similar with each other. A careful inspection reveals the existence of crystals with different sizes, dispersed over an amorphous matrix with different contrasts. The average particle sizes of these crystals are respectively about 12,32 and $68 \mathrm{~nm}$. It is very difficult to know if the observed contrast is associated to $\mathrm{CeO}_{2}, \mathrm{ZrO}_{2}$ or PdO particles, the accurate measurement of the particle size of Pd cannot be achieved [19]. Ye Yuan et al. [20] indicated that most of the Pd particles on a $\mathrm{CeO}_{2}$ support could not be observed even when HR-TEM was utilized. But according to the chemisorption results the Pd particle size did not exceed $7 \mathrm{~nm}$, which does not make such particles visible on the TEM images. For this reason, the $\mathrm{CeO}_{2}$ and $\mathrm{ZrO}_{2}$ identification can be based on their particle growth. Contrarily, to the Pd particles which are more dispersed. These results are in agreement with those of Y. T. Kim et al. [21]. The existence of palladium particles is confirmed by EDX analysis (Figure 2(e)), which confirms the existence of $\mathrm{Pd}, \mathrm{Ce}$ and $\mathrm{Zr}$. This result suggests that metallic oxides are well dispersed [13].

\subsection{XPS}

XPS results indicated that palladium is only present as $\mathrm{PdO}\left(\mathrm{Pd}^{2+}\right)$ species for all catalysts. The $\mathrm{Pd} 3 \mathrm{~d}_{5 / 2}$ binding energies for the all $\mathrm{Pd} /\left(\mathrm{Ce}_{0.33} \mathrm{Zr}_{0.66} \mathrm{O}_{2}\right) \mathrm{SiO}_{2}$ catalysts fall in the range of $336.4-337.0 \mathrm{eV}$ (Table 2). Generally, the $\mathrm{Pd}_{3 / 2}$ binding energy for $\mathrm{Pd}^{0}$ and $\mathrm{Pd}^{2+}$ are about $334.9 \pm 0.1 \mathrm{eV}$ and $336.4 \pm 0.1 \mathrm{eV}$, respectively [19]. Here, the $P d 3 d_{5 / 2}$ binding energies on CeZr8 CeZr4, CeZr2 and CeZr0 samples are respectively 336.8, 337.0, 336.5 and $336.4 \mathrm{eV}$ (Figure 3). According to the literature, values between 336.8 and $337.0 \mathrm{eV}$ are slightly too high for indicating the presence of pure $\mathrm{PdO}\left(\mathrm{Pd}^{2+}, 336.4 \pm 0.1 \mathrm{eV}\right)$. This increase can be related to the interaction between $\mathrm{PdO}$ and the $\mathrm{CeZr}-\mathrm{O}_{2} / \mathrm{SiO}_{2}$ support [16]. Furthermore, the relatively high $\mathrm{Pd}_{5 / 2} \mathrm{BE}$ on the CeZr4 catalysts $(337.0 \mathrm{eV})$ indicates that optimum amounts of $\operatorname{Zr}(4 \mathrm{wt} . \%)$ and $\mathrm{Ce}(3 \mathrm{wt} . \%)$ are needed to enhance the interaction between Pd species and the support. According to the XPS results, no $\mathrm{Pd}^{0}$ is detected on catalyst surface. Ciuparu et al. [22], explained

Table 2. Pd binding energies and surface atomic composition of the $\mathrm{Pd} /\left(\mathrm{Ce}_{0.33} \mathrm{Zr}_{0.66} \mathrm{O}_{2}\right)$ $\mathrm{SiO}_{2}$ catalysts.

\begin{tabular}{|c|c|c|c|c|}
\hline Sample & $\mathrm{BE} \mathrm{Pd} 3 \mathrm{~d}_{3 / 2}(\mathrm{eV})$ & BE Pd $3 d_{5 / 2}(e V)$ & Oxidation state & $\operatorname{Pd}(\%)$ \\
\hline CeZr8 & 342.1 & 336.8 & $\mathrm{Pd}^{2+}$ & 0.02 \\
\hline CeZr4 & 342.3 & 337.0 & $\mathrm{Pd}^{2+}$ & 0.02 \\
\hline CeZr2 & 341.4 & 336.5 & $\mathrm{Pd}^{2+}$ & 0.02 \\
\hline CeZro & 341.4 & 336.4 & $\mathrm{Pd}^{2+}$ & 0.02 \\
\hline
\end{tabular}




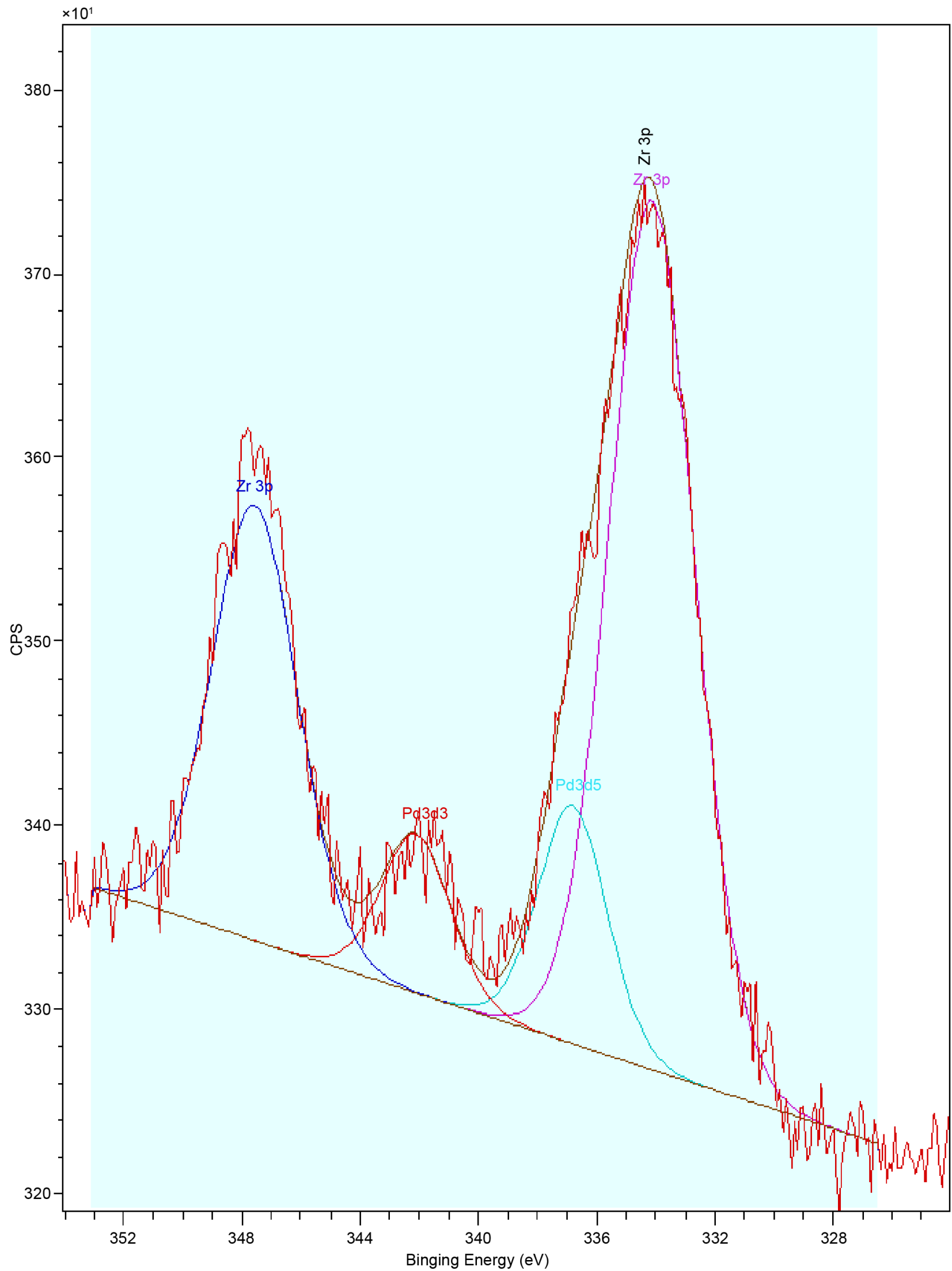




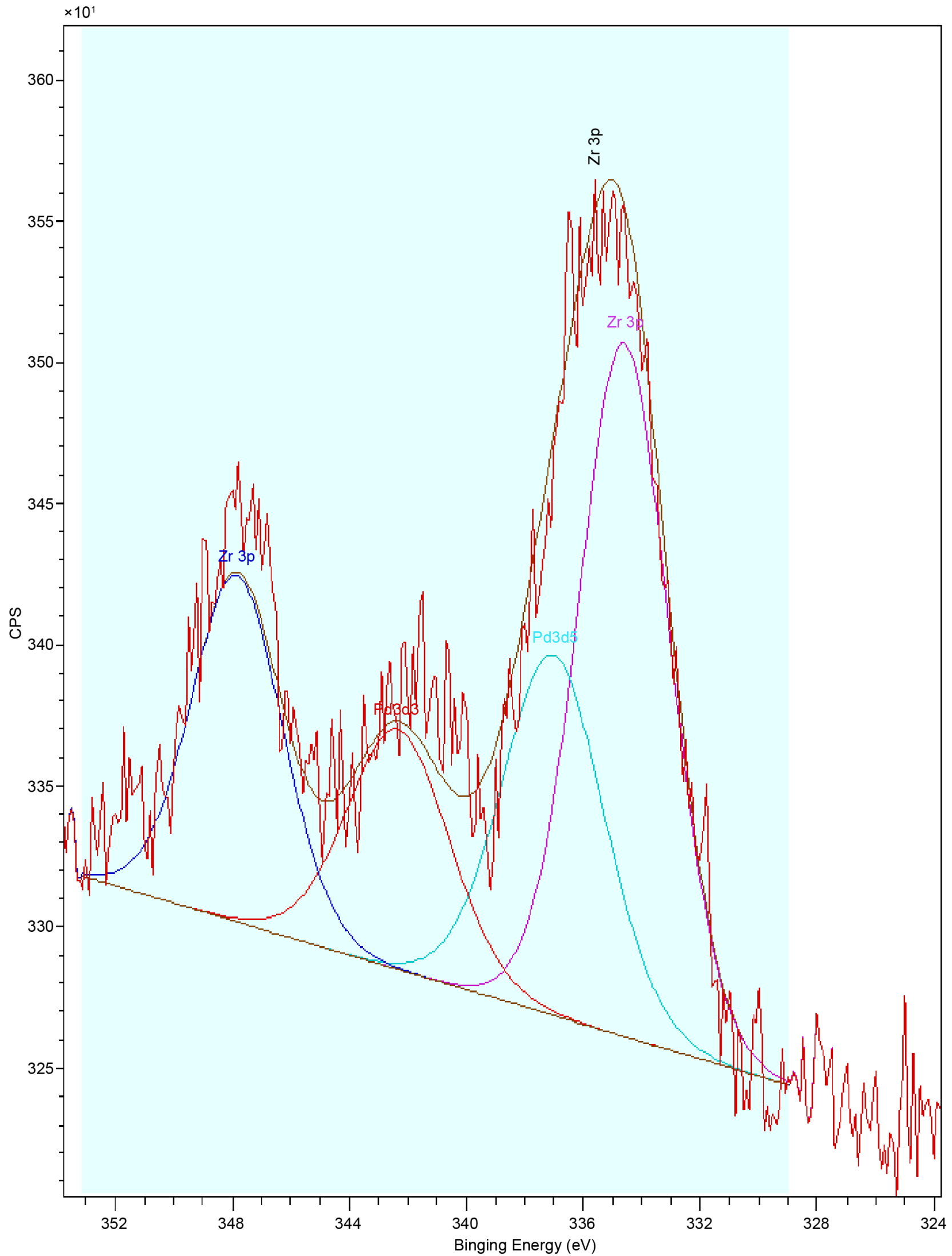




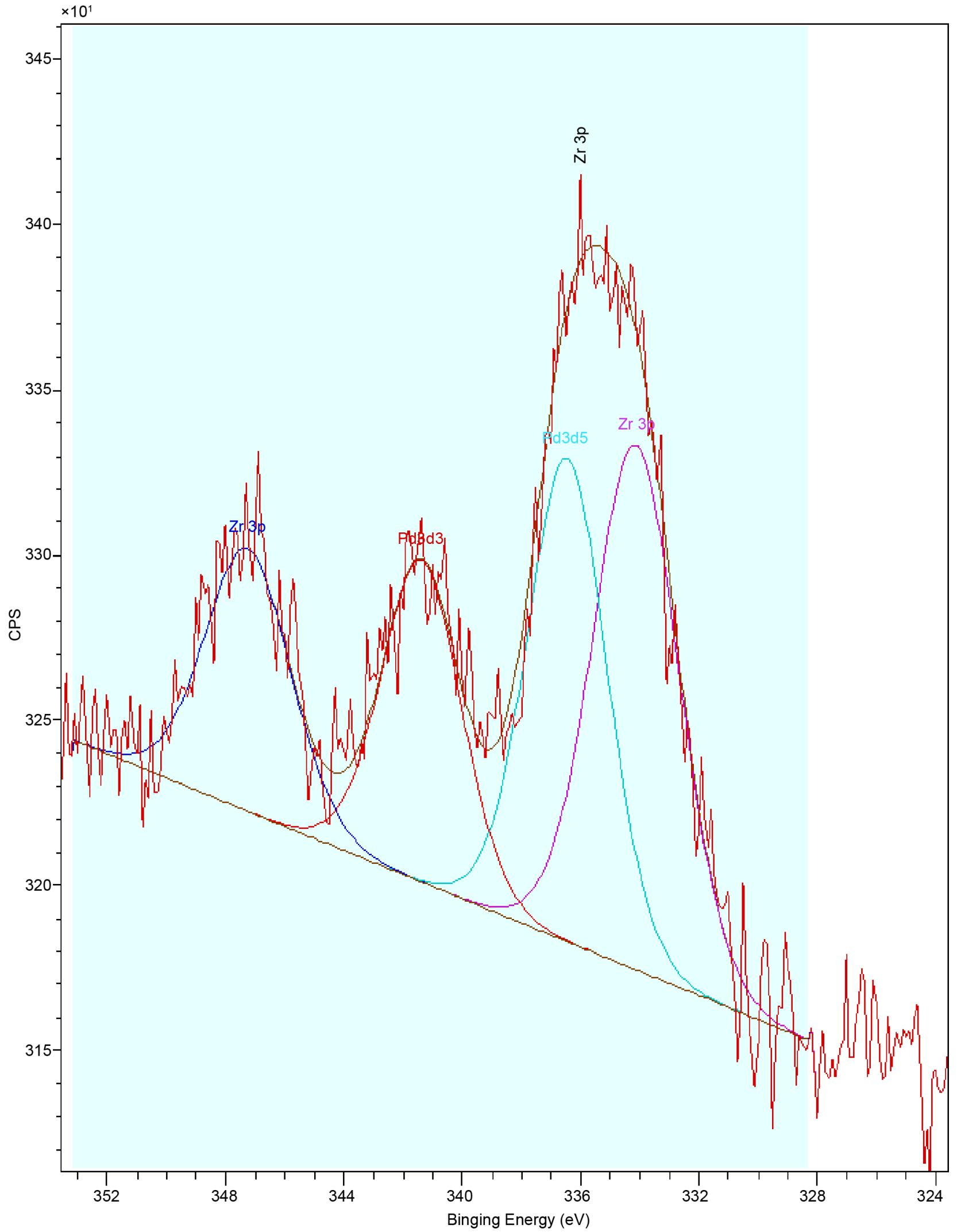

Figure 3. XPS patterns of the $\mathrm{Pd} /\left(\mathrm{Ce}_{0.33} \mathrm{Zr}_{0.66} \mathrm{O}_{2}\right) \mathrm{SiO}_{2}$ catalysts: (a) CeZr2, (b) $\mathrm{CeZr} 4$ and (c) $\mathrm{CeZr}$. 
this result by the phase with lower surface tension tends to encapsulate the phase with higher surface tension. Knowing that oxides have lower surface tension than metals, so the absence of metallic Pd contribution may be explained encapsulated by PdO oxides.

Furthermore, it is important to note that the surface loadings of palladium remains quasi-constant (about $0.02 \%$ ) with the increase of $\mathrm{Ce}$ and $\mathrm{Zr}$ amount.

\subsection{TPR}

The TPR profiles of the $\mathrm{Pd} /\left(\mathrm{Ce}_{0.33} \mathrm{Zr}_{0.66} \mathrm{O}_{2}\right) \mathrm{SiO}_{2}$ catalyst are shown in Figure 4 . The negative signals observed below $50^{\circ} \mathrm{C}$, designated as peak $\alpha$ and peak $\beta$ correspond respectively to the reduction of the larger $\mathrm{PdO}$ species dispersed on the catalyst surface and to the reduction of the smaller PdO species having higher interaction with the support [19] [23]. Therefore, they are more stable than the larger PdO species. However, the positive signal, designated as peak $\gamma$ is attributed to the decomposition of the PdHx species formed during the PdO reduction [23]. According to the obtained results (Table 3), the introduction of $\mathrm{Zr}$ and $\mathrm{Ce}$ on the $\mathrm{Pd} / \mathrm{SiO}_{2}$ catalyst affects the PdOx reducibility. This reducibility increased in the following order: CeZr0 $<\mathrm{CeZr} 8<\mathrm{CeZr} 2<\mathrm{CeZr} 4$. Consequently, the introduction of ceria and zirconia improved the $\mathrm{PdO}$ redox property [24]. However, an optimum amounts equal to $4 \mathrm{wt} . \%$ of $\mathrm{Zr}$ and $3 \mathrm{wt} . \%$ of $\mathrm{Ce}$ are needed to maximize the $\mathrm{PdO}$ reducibility which is a key factor determining the oxidation performance of Pd-based catalysts [25].

\subsection{Catalytic Activity}

The methane conversion curves of the $\mathrm{Pd} /\left(\mathrm{Ce}_{0.33} \mathrm{Zr}_{0.66} \mathrm{O}_{2}\right) \mathrm{SiO}_{2}$ catalysts prepared with different $\mathrm{Zr}$ and Ce loadings are presented in Figure 5. The $T_{20}, T_{50}$ and $\mathrm{T}_{100}$ values (respectively temperatures for $20 \%, 50 \%$ and $100 \%$ of methane conversion) (Table 4), decreased when the $\mathrm{Zr}$ loading increased from $0 \%$ to $4 \%$ and

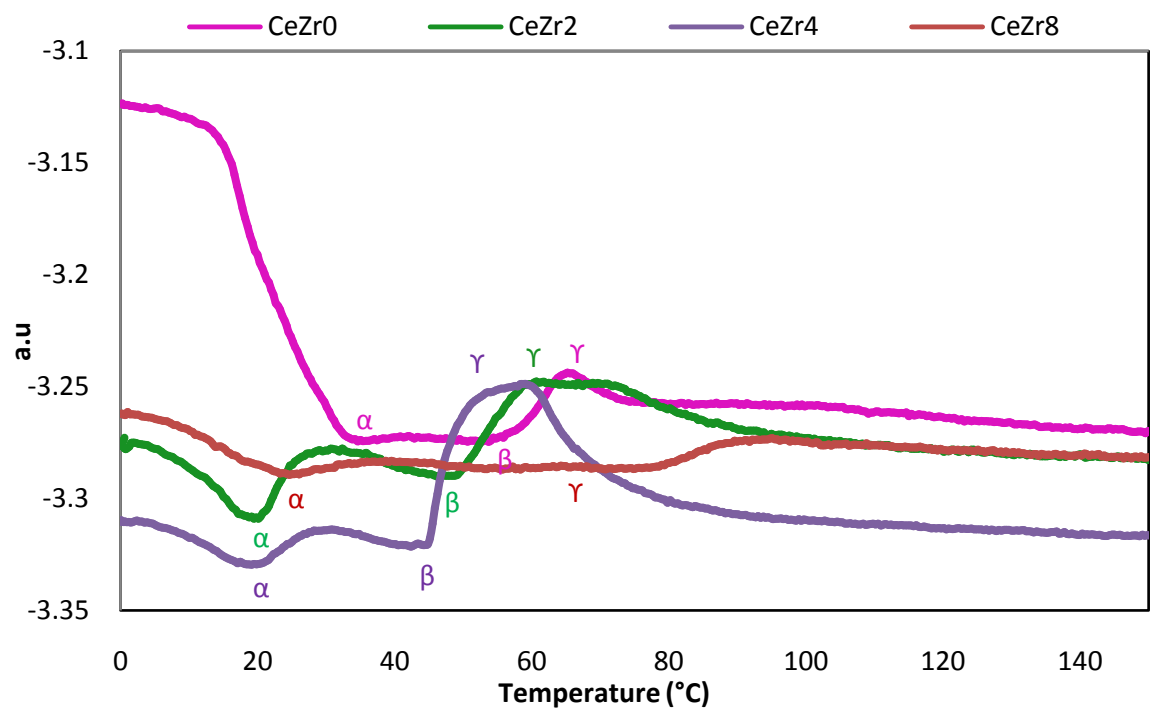

Figure 4. TPR profiles of the $\mathrm{Pd} /\left(\mathrm{Ce}_{0.33} \mathrm{Zr}_{0.66} \mathrm{O}_{2}\right) \mathrm{SiO}_{2}$ catalysts. 
Table 3. Reduction temperatures of the $\mathrm{Pd} /\left(\mathrm{Ce}_{0.33} \mathrm{Zr}_{0.66} \mathrm{O}_{2}\right) \mathrm{SiO}_{2}$ catalysts.

\begin{tabular}{cccc}
\hline Sample & $\mathrm{T}\left({ }^{\circ} \mathrm{C}\right)$ & $\mathrm{T}\left({ }^{\circ} \mathrm{C}\right)$ & $\mathrm{T}\left({ }^{\circ} \mathrm{C}\right)$ \\
\hline CeZr8 & 23 & 49 & 64 \\
CeZr4 & 16 & 37 & 58 \\
CeZr2 & 18 & 43 & 60 \\
CeZr0 & 32 & 47 & 65 \\
\hline
\end{tabular}

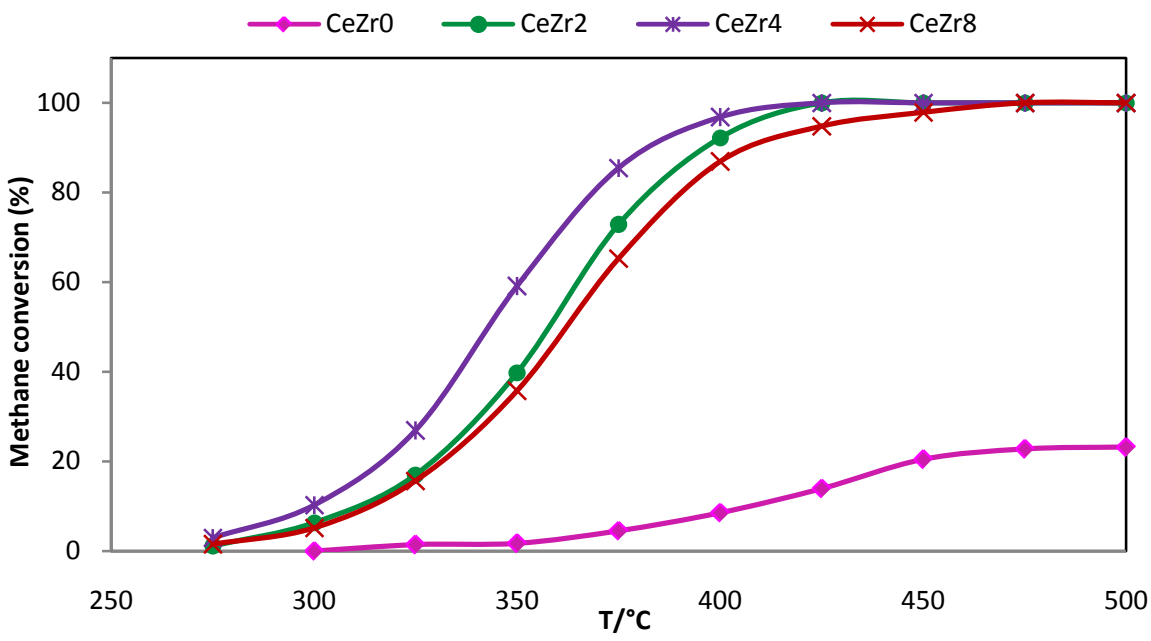

Figure 5. Effect of the $\mathrm{Zr}$ and Ce loadings on the activity of $\mathrm{Pd} /\left(\mathrm{Zr}_{0.66} \mathrm{Ce}_{0.33} \mathrm{O}_{2}\right) \mathrm{SiO}_{2}$ catalysts.

Table 4. Light-off temperature and turnover number at $325^{\circ} \mathrm{C}$ of the $\mathrm{Pd} /\left(\mathrm{Ce}_{0.33} \mathrm{Zr}_{0.66} \mathrm{O}_{2}\right)$ $\mathrm{SiO}_{2}$ catalysts.

\begin{tabular}{ccccc}
\hline Sample & $\mathrm{T}_{20}\left({ }^{\circ} \mathrm{C}\right)$ & $\mathrm{T}_{50}\left({ }^{\circ} \mathrm{C}\right)$ & $\mathrm{T}_{100}\left({ }^{\circ} \mathrm{C}\right)$ & $\mathrm{TOF}^{\mathrm{a}}\left(\mathrm{h}^{-1}\right)$ \\
\hline CeZr8 & 331 & 362 & 462 & 875 \\
CeZr4 & 317 & 342 & 415 & 1588 \\
CeZr2 & 329 & 358 & 425 & 1243 \\
CeZr0 & 450 & - & - & 157 \\
\hline
\end{tabular}

a Turnover frequency (TOF) at $325^{\circ} \mathrm{C}$.

then increased with the further $\mathrm{Zr}$ loading increase to $8 \%$. Thus the presence of cerium and zirconium oxides would obviously improve the thermal stability of $\mathrm{PdO}$ phase of the $\mathrm{Pd} / \mathrm{SiO}_{2}$ catalysts and enhance the catalytic activity. This is in agreement with our previous research. In fact, I. B. Said et al. [13] show that the addition of $\mathrm{Ce}$ and $\mathrm{Zr}$ to the $\mathrm{Pd} / \mathrm{MCM}-41$ enhance the catalytic activity for methane combustion, and an appropriate amount of these oxides can improve significantly its catalytic activity. In our case, this optimum corresponds to $4 \%$ of $\mathrm{Zr}$ and 3\% of Ce. Considering the similar textural properties of CeZr4 and CeZr2 samples, the differences in the catalytic performance is mainly dependent on the reduction and structural properties. The TPR results show that improved 
reducibility is obtained with increasing the doping amount of $\mathrm{Zr}$ in the following order: $\mathrm{CeZr} 0<\mathrm{CeZr} 2<\mathrm{CeZr} 4$. Furthermore these results suggest that the activity of the catalytic sites is enhanced by the improvement of the PdO reducibility. In addition, according to the XPS results, the increase in $\mathrm{Zr}$ and Ce amounts stabilizes palladium particles in $\mathrm{PdO}$ state and allows a strong interaction of PdO with the support, which enhances the re-oxidation properties of PdO.

Moreover, in the case of CeZr8 catalyst, the increase of Ce and $\mathrm{Zr}$ amount decrease the catalytic activity compared to that of CeZr4 and CeZr2 samples. As can be noted, similar dispersion and textural propriety are obtained for all catalysts. Thus, the reason how could mainly explain the activity drop is the Pd reducibility.

The turnover number frequency (TOF) has been calculated to investigate the effect of $\mathrm{Ce}$ and $\mathrm{Zr}$ introduction in the activity per site. As summarized in Table 4. it is clearly observed that the CeZr4 sample exhibit a relatively high TOF $\left(1588 \mathrm{~h}^{-1}\right)$, in the combustion of methane at $325^{\circ} \mathrm{C}$, followed by CeZr2 $(1243$ $\left.\mathrm{h}^{-1}\right)$, CeZr8 $\left(875 \mathrm{~h}^{-1}\right)$ and CeZr0 $\left(157 \mathrm{~h}^{-1}\right)$. From the obtained results, the TOF evolution can explain the activity decreases. The TOF is inversely proportional to the reduction temperature order. The higher the reduction temperature, the lower is the turnover number. As a conclusion, optimum values of $\mathrm{Ce}$ and $\mathrm{Zr}$ should be reached to maximize activity in methane combustion.

\section{Conclusions}

The following conclusions can be drawn from this work:

- The impregnation of the $\left(\mathrm{Ce}_{0.33} \mathrm{Zr}_{0.66} \mathrm{O}_{2}\right) \mathrm{SiO}_{2}$ aerogel support with palladium and the optimization of the $\mathrm{Ce}$ and $\mathrm{Zr}$ contents enable producing mesoporous $\mathrm{Pd} /\left(\mathrm{Ce}_{0.33} \mathrm{Zr}_{0.66} \mathrm{O}_{2}\right) \mathrm{SiO}_{2}$ catalysts with relatively high specific surface areas;

- The palladium dispersion is improved when the $\mathrm{Zr}$ and Ce loading are increased on the $\mathrm{Pd} /\left(\mathrm{Ce}_{0.33} \mathrm{Zr}_{0.66} \mathrm{O}_{2}\right) \mathrm{SiO}_{2}$ catalysts;

- With the preparation method adopted in this work, relatively small particles of $\mathrm{CeO}_{2}$ and $\mathrm{ZrO}_{2}$ oxides, are obtained on the $\mathrm{Pd} /\left(\mathrm{Ce}_{0.33} \mathrm{Zr}_{0.66} \mathrm{O}_{2}\right) \mathrm{SiO}_{2}$ catalysts.

- The $\mathrm{Pd} 3 \mathrm{~d}_{5 / 2}$ photopeak binding energy increased with the Ce and $\mathrm{Zr}$ amount increase. This seems to be due to a strong interaction between PdO and $\mathrm{CeO}_{2}-\mathrm{ZrO}_{2}$;

- The addition of $\mathrm{Ce}$ and $\mathrm{Zr}$ to $\mathrm{Pd} / \mathrm{SiO}_{2}(\mathrm{CeZr} 0)$ improves the $\mathrm{PdO}$ redox property and an optimum amounts of $\mathrm{Zr}$ and $\mathrm{Ce}$ is observed, for which the PdO reducibility is maximized; The improvement of the $\mathrm{Pd} /\left(\mathrm{Ce}_{0.33} \mathrm{Zr}_{0.66} \mathrm{O}_{2}\right) \mathrm{SiO}_{2}$ reducibility is most likely responsible for the observed catalytic activity enhancement in the methane combustion reaction.

\section{Acknowledgements}

Chevreul Institute (FR 2638), Ministère de l'Enseignement Supérieur et de la Recherche, Région Nord-Pas de Calais and FEDER are acknowledged for supporting and funding partially this work. 


\section{References}

[1] Liu, C., Xian, H., Jiang, Z., Wang, L., Zhang, J., Zheng, L., Tan, Y. and Li, X. (2015) Insight into the Improvement Effect of the Ce Doping into the $\mathrm{SnO}_{2}$ Catalyst for the Catalytic Combustion of Methane. Applied Catalysis B: Environmental, 176-177, 542-552.

[2] Di Iorio, S., Sementa, P. and Vaglieco, B.M. (2016) Analysis of Combustion of Methane and Hydrogen-Methane Blends in Small DI SI (Direct Injection Spark Ignition) Engine using Advanced Diagnostics. Energy, 108, 99-107.

[3] Cao, L., Pan, L., Ni, C., Yuan, Z. and Wang, S. (2010) Autothermal Reforming of Methane over $\mathrm{Rh} / \mathrm{Ce}_{0.5} \mathrm{Zr}_{0.5} \mathrm{O}_{2}$ Catalyst: Effects of the Crystal Structure of the Supports. Fuel Processing Technology, 91, 306-312. https://doi.org/10.1016/j.fuproc.2009.11.001

[4] Fan, X., Wang, F., Zhu, T. and He, H. (2012) Effects of Ce on Catalytic Combustion of Methane over Pd-Pt/ $\mathrm{Al}_{2} \mathrm{O}_{3}$ Catalyst. Journal of Environmental Sciences, 24, 507-511. https://doi.org/10.1016/S1001-0742(11)60798-5

[5] Fessi, S., Mamede, A.S., Ghorbel, A. and Rives, A. (2012) Sol-Gel Synthesis Combined with Solid-Solid Exchange Method, a New Alternative Process to Prepare Improved $\mathrm{Pd} / \mathrm{SiO}_{2}-\mathrm{Al}_{2} \mathrm{O}_{3}$ Catalysts for Methane Combustion. Catalysis Communications, 27, 109-113. https://doi.org/10.1016/j.catcom.2012.06.016

[6] Okal, J., Zawadzki, M. and Baranowska, K. (2016) Methane Combustion over Bimetallic Ru-Re/ $\gamma-\mathrm{Al}_{2} \mathrm{O}_{3}$ Catalysts: Effect of Re and Pretreatments. Applied Catalysis B: Environmental, 194, 22-31.

[7] Gholami, R., Alyani, M. and Smith, K.J. (2015) Deactivation of Pd Catalysts by Water during Low Temperature Methane Oxidation Relevant to Natural Gas Vehicle Converters. Catalysts, 5, 561-594. https://doi.org/10.3390/catal5020561

[8] Fan, X., Wang, F., Zhu, T.L. and He, H. (2012) Effects of Ce on Catalytic Combustion of Methane over Pd-Pt/ $\mathrm{Al}_{2} \mathrm{O}_{3}$ Catalyst. Journal of Environmental Sciences, 24, 507-511. https://doi.org/10.1016/S1001-0742(11)60798-5

[9] Zhou, Z.L., Ji, S.F., Yin, F.X., Lu, Z.X. and Li, C.Y. (2007) Preparation of $\mathrm{Pd} / \mathrm{Ce}_{\mathrm{x}} \mathrm{Zr}_{1-\mathrm{x}} \mathrm{O}_{2} / \mathrm{SiO}_{2}$ and Its Catalytic Performance in Methane Combustion. Journal of Fuel Chemistry and Technology, 35, 583-588. https://doi.org/10.1016/S1872-5813(07)60035-8

[10] Ferrer, V., Finol, D., Rodríguez, D., Domínguez, F., Solano, R., Zárraga, J. and Sánchez, J. (2009) Chemical Characterization and Catalytic Activity of Pd-Supported Catalysts on $\mathrm{Ce}_{0.39} \mathrm{Zr}_{0.61} \mathrm{O}_{x} / \mathrm{SiO}_{2}$. Catalysis Letters, 132, 292-298. https://doi.org/10.1007/s10562-009-0115-8

[11] Ruiz, J.A.C., Oliveira, E.C., Fraga, M.A. and Pastore, H.O. (2012) Performance of Pd Supported on Mesoporous Molecular Sieves on Methane Combustion. Catalysis Communications, 25, 1-6. https://doi.org/10.1016/j.catcom.2012.04.006

[12] Kozlov, A., Kim, D., Yezerets, A., Andersen, P., Kung, H. and Kung, M. (2002) Oxidative Dehydrogenation of Alkanes over Vanadium-Magnesium-Oxides. Journal of Catalysis, 209, 417-426. https://doi.org/10.1006/jcat.2002.3644

[13] Saïd, I.B., Sadouki, K., Masse, S., Coradin, T., Smiri, L. and Fessi, S. (2018) Advanced $\mathrm{Pd} / \mathrm{CexZr}_{(1-\mathrm{x})} \mathrm{O}_{2} / \mathrm{MCM}-41$ Catalysts for Methane Combustion: Effect of the Zirconium and Cerium Loadings. Microporous and Mesoporous Materials, 260, 93-101. https://doi.org/10.1016/j.micromeso.2016.10.044

[14] Satterfield, C. (1980) Heterogeneus Catalysis in Practice. McGraw Hill, New York, 93. 
[15] Graham, G.W., Schmitz, P.J., Usmen, R.K. and McCabe, R.W. (1993) Investigation of $\mathrm{La}^{3+}$-Modified $\mathrm{Al}_{2} \mathrm{O}_{3}$ Supported $\mathrm{CeO}_{2}$. Catalysis Letters, 17, 175-184. https://doi.org/10.1007/BF00763940

[16] Vidmar, P., Fornasiero, P., Kaspar, J., Gubitosa, G. and Graziani, M. (1997) Effects of Trivalent Dopants on the Redox Properties of $\mathrm{Ce}_{0.6} \mathrm{Zr}_{0.4} \mathrm{O}_{2}$ Mixed Oxide. Journal of Catalysis, 171, 160-168. https://doi.org/10.1006/jcat.1997.1784

[17] Wang, X., Lu, G., Guo, Y., Qiao, D., Zhang, Z., Guo, Y. and Li, C. (2008) Properties of $\mathrm{CeO}_{2}-\mathrm{ZrO}_{2}$ Solid Solution Supported on Si-Modified Alumina and Its Application in Pd Catalyst for Methane Combustion. Chinese Journal of Catalysis, 29, 1043-1050. https://doi.org/10.1016/S1872-2067(08)60081-9

[18] Yin, F., Ji, S., Wu, P., Zhao, F. and Li, C. (2008) Deactivation Behavior of Pd-Based SBA-15 Mesoporous Silica Catalysts for the Catalytic Combustion of Methane. Journal of Catalysis, 257, 108-116. https://doi.org/10.1016/j.jcat.2008.04.010

[19] Wang, G., You, R. and Meng, M. (2013) An Optimized Highly Active and Thermo-Stable Oxidation Catalyst $\mathrm{Pd} / \mathrm{Ce}-\mathrm{Zr}-\mathrm{Y} / \mathrm{Al}_{2} \mathrm{O}_{3}$ Calcined at Superhigh Temperature and Used for $\mathrm{C}_{3} \mathrm{H}_{8}$ Total Oxidation. Fuel, 103, 799-804. https://doi.org/10.1016/j.fuel.2012.08.051

[20] Yuan, Y., Wang, Z., An, H., Xue, W. and Wang, Y. (2015) Oxidative Carbonylation of Phenol with a Pd-O/CeO - Nanotube Catalyst. Chinese Journal of Catalysis, 36, 1142-1154. https://doi.org/10.1016/S1872-2067(14)60312-0

[21] Kim, Y.T., You, S.J. and Park, E.D. (2012) Water-Gas Shift Reaction over Pt and $\mathrm{Pt}-\mathrm{CeO}_{\mathrm{x}}$ Supported on $\mathrm{CexZr}_{1-\mathrm{x}} \mathrm{O}_{2}$. International Journal of Hydrogen Energy, 37, 1465-1474. https://doi.org/10.1016/j.ijhydene.2011.10.014

[22] Ciuparu, D., Pfefferle, L.D. and Datye, A. (2002) Catalytic Combustion of Methane over Palladium-Based Catalysts. Catalysis Reviews-Science and Engineering, 44, 593-649. https://doi.org/10.1081/CR-120015482

[23] Zhao, B., Yang, C., Wang, Q., Li, G. and Zhou, R. (2010) Influence of Thermal Treatment on Catalytic Performance of $\mathrm{Pd} /(\mathrm{Ce}, \mathrm{Zr}) \mathrm{O}_{\mathrm{x}}-\mathrm{Al}_{2} \mathrm{O}_{3}$ Three-Way Catalysts. Journal of Alloys and Compounds, 494, 340-346. https://doi.org/10.1016/j.jallcom.2010.01.031

[24] Zhou, Z.-L., Ji, S.-F., Yin, F.-X., Lu, Z.-X. and Li, C.-Y. (2007) Preparation of $\mathrm{Pd} / \mathrm{Ce}_{\mathrm{x}} \mathrm{Zr}_{1-\mathrm{x}} \mathrm{O}_{2} / \mathrm{SiO}_{2}$ and Its Catalytic Performance in Methane Combustion. Journal of Fuel Chemistry and Technology, 35, 583-588. https://doi.org/10.1016/S1872-5813(07)60035-8

[25] Xie, S., Liu, Y., Deng, J., Zhao, X., Yang, J., Zhang, K., Han, Z. and Dai, H. (2016) Three-Dimensionally Ordered Macroporous $\mathrm{CeO}_{2}$-Supported Pd@Co Nanoparticles: Highly Active Catalysts for Methane Oxidation. Journal of Catalysis, 342, 17-26. https://doi.org/10.1016/j.jcat.2016.07.003 